\title{
A relaxed eddy accumulation system for measuring vertical fluxes of nitrous acid
}

\author{
X. Ren ${ }^{1, *}$, J. E. Sanders ${ }^{1}$, A. Rajendran ${ }^{1, * *}$, R. J. Weber ${ }^{2}$, A. H. Goldstein ${ }^{2}$, S. E. Pusede ${ }^{3}$, E. C. Browne ${ }^{3}$, K.-E. Min ${ }^{4}$, \\ and R. C. Cohen ${ }^{3,4}$ \\ ${ }^{1}$ Rosenstiel School of Marine and Atmospheric Science, University of Miami, Miami, FL, USA \\ ${ }^{2}$ Department of Environmental Science, Policy, and Management, University of California at Berkeley, Berkeley, CA, USA \\ ${ }^{3}$ Department of Chemistry, University of California at Berkeley, Berkeley, CA, USA \\ ${ }^{4}$ Department of Earth and Planetary Science, University of California at Berkeley, Berkeley, CA, USA \\ * now at: Air Resources Laboratory, National Oceanic and Atmospheric Administration, Silver Spring, MD, USA \\ ** now at: Department of Epidemiology and Public Health, University of Miami, Miami, FL, USA
}

Received: 6 June 2011 - Published in Atmos. Meas. Tech. Discuss.: 29 June 2011

Revised: 4 September 2011 - Accepted: 4 October 2011 - Published: 7 October 2011

\begin{abstract}
A relaxed eddy accumulation (REA) system combined with a nitrous acid (HONO) analyzer was developed to measure atmospheric HONO vertical fluxes. The system consists of three major components: (1) a fast-response sonic anemometer measuring both vertical wind velocity and air temperature, (2) a fast-response controlling unit separating air motions into updraft and downdraft samplers by the sign of vertical wind velocity, and (3) a highly sensitive HONO analyzer based on aqueous long path absorption photometry that measures HONO concentrations in the updrafts and downdrafts. A dynamic velocity threshold $\left( \pm 0.5 \sigma_{w}\right.$, where $\sigma_{w}$ is a standard deviation of the vertical wind velocity) was used for valve switching determined by the running means and standard deviations of the vertical wind velocity. Using measured temperature as a tracer and the average values from two field deployments, the flux proportionality coefficient, $\beta$, was determined to be $0.42 \pm 0.02$, in good agreement with the theoretical estimation. The REA system was deployed in two ground-based field studies. In the California Research at the Nexus of Air Quality and Climate Change (CalNex) study in Bakersfield, California in summer 2010, measured HONO fluxes appeared to be upward during the day and were close to zero at night. The upward HONO flux was highly correlated to the product of $\mathrm{NO}_{2}$ and solar radiation. During the Biosphere Effects on Aerosols and Photochemistry Ex-
\end{abstract}

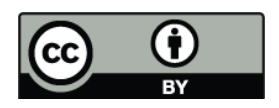

Correspondence to: $\mathrm{X}$. Ren (xren@rsmas.miami.edu) periment (BEARPEX 2009) at Blodgett Forest, California in July 2009, the overall HONO fluxes were small in magnitude and were close to zero. Causes for the different HONO fluxes in the two different environments are briefly discussed.

\section{Introduction}

The traditional eddy covariance (EC) technique for flux measurement requires the use of sensors that can respond at fast frequencies $(\sim 10 \mathrm{~Hz})$. This constraint cannot always be met for the measurement of many atmospheric chemical species. The relaxed eddy accumulation (REA) method thus represents great potential as a suitable alternative for the EC technique for micrometeorological flux measurement of atmospheric species when fast response sensors are unavailable. The REA method was derived from the eddy accumulation (EA) method that was first suggested by Desjardins (1972) and involves sampling the air depending on the magnitude and direction of the vertical wind velocity. The REA method, proposed by Businger and Oncley (1990), separates the air samples into updraft and downdraft reservoirs at a constant flow rate, based solely on the sign of the vertical wind. Concentrations in the updraft and downdraft eddy motions are determined by an analytical sensor and the flux is calculated proportional to the difference in concentration between the updrafts and downdrafts (Meyers et al., 2006). Details on the theory and derivation of the REA technique can be found in the literature (e.g., Businger and Oncley, 1990; Baker et al.,

Published by Copernicus Publications on behalf of the European Geosciences Union. 
1992; Dabberdt et al., 1993; Pattey et al., 1993). Because insitu concentration measurements are not necessary, the REA technique also allows for the use of laboratory instrumentation, which may have higher accuracy than portable sensors but is too bulky or delicate for field use (Nie et al., 1995).

The REA technique has increased in popularity and has been successfully used to measure the fluxes of a number of traces gases and aerosols, for example volatile organic compounds (Guenther et al., 1996; Valentini et al., 1997; Bowling et al., 1998; Pattey et al., 1999; Gallagher et al. 2000; Schade and Goldstein, 2001; Olofsson et al., 2003; Hornsby et al., 2009), ammonia (Zhu et al., 2000), stable isotope of ${ }^{13} \mathrm{C}^{16} \mathrm{O}_{2}$ and ${ }^{12} \mathrm{C}^{18} \mathrm{O}^{16} \mathrm{O}$ (Bowling et al., 1999), nitrous oxide (Xi et al., 1996), total gaseous mercury (Cobos et al., 2002; Olofsson et al., 2005; Bash and Miller, 2008), and aerosol particle numbers (Schery et al., 1998; Gaman et al., 2004). There are only a few attempts to measure atmospheric nitrous acid (HONO) fluxes, mostly derived from the gradient method (e.g., Harrison and Kitto, 1994; Neftel et al., 1996; Honrath et al., 2002; Stutz et al., 2002; Beine et al., 2005, 2006). To our knowledge, there are very limited HONO flux measurements using the REA method (Bertman et al., 2003; Zhou et al., 2011). Nitrous acid (HONO) plays an important role in atmospheric chemistry because of its photolysis to form the hydroxyl $(\mathrm{OH})$ radical, the most important atmospheric oxidant (Alicke et al., 2003; Kleffmann et al., 2005; Ren et al., 2006; Mao et al., 2010). Significant daytime HONO levels and fast HONO loss through its photolysis indicate that a strong HONO production rate exists in many environments. This suggests that HONO plays an important role in total reactive nitrogen $\left(\mathrm{NO}_{\mathrm{y}}\right)$ cycling (Ren et al., 2010), despite the fact that HONO usually constitutes a small fraction of $\mathrm{NO}_{\mathrm{y}}$. Measurement of HONO concentrations and fluxes is thus of great interest and is important to understand the roles HONO plays in atmospheric photochemistry and nitrogen budget.

In this paper, we present the development of a REA system for the measurement of atmospheric HONO fluxes. The REA system was characterized and deployed in two field studies: the California Research at the Nexus of Air Quality and Climate Change (CalNex 2010) study in Bakersfield, California in summer 2010 and the Biosphere Effects on Aerosols and Photochemistry Experiment (BEARPEX 2009) at Blodgett Forest, California in July 2009. Measurement results of HONO fluxes in these two field studies are briefly discussed.

\section{Methods}

\subsection{Relaxed eddy accumulation}

A relaxed eddy accumulation (REA) system was developed to measure atmospheric HONO vertical fluxes. The system samples wind eddies based on the sign of vertical wind velocity over an extended time interval. Updraft $\left(w^{+}\right)$ and downdraft $\left(w^{-}\right)$air samples are collected into separate HONO samplers when the vertical wind velocities are out of a deadband (defined below). The vertical mass flux of HONO $\left(F_{\mathrm{HONO}}\right)$ can be determined by the following equation (Businger and Oncley, 1990):

$F_{\mathrm{HONO}}=\beta \sigma_{w}\left(\bar{C}_{\text {up }}-\bar{C}_{\text {down }}\right)$

where, $\sigma_{w}$ is the standard deviation of the vertical wind velocity, $\bar{C}_{\text {up }}$ and $\bar{C}_{\text {down }}$ are the average HONO concentrations in the updrafts and downdrafts, respectively, and $\beta$ is the flux proportionality coefficient. The calculation of $\beta$ is described in Sect. 3.1.

A dynamic velocity deadband of $0.5 \sigma_{w}$ was implemented to maximize the difference between updraft and downdraft concentrations. Such a varying threshold made the flux proportionality coefficient, $\beta$, independent of observation conditions (Gaman et al., 2004). Instantaneous vertical wind velocity was sampled and the moving averages $(\bar{w})$ and standard deviations $\left(\sigma_{w}\right)$ of vertical wind velocity during the predefined running average interval (set to $5 \mathrm{~min}$, which is used by a REA method (e.g., Nie et al., 1995)) were calculated. When the deviation of current vertical wind velocity $\left(w^{+}=w-\bar{w}\right)$ was greater than $+0.5 \sigma_{w}$, the air sample flow was diverted to the updraft sampler to measure HONO in the updraft air samples $\left(\bar{C}_{\text {up }}\right)$. When the deviation of vertical wind velocity $\left(w^{-}=w-\bar{w}\right)$ was smaller than $-0.5 \sigma_{w}$, the air sample flow was diverted to the downdraft sampler to measure HONO in the downdraft air samples $\left(\bar{C}_{\text {down }}\right)$. Concentrations of $\mathrm{HONO}$ in the updraft and downdraft samples were then measured by a HONO analyzer as described in Sect. 2.2.

Our REA-HONO system consists of a 3-D sonic anemometer (Campbell Scientific, Model CST3), a controlling unit to divert air into updraft and downdraft samplers depending on the sign of vertical wind velocity, and a HONO analyzer (described in Sect. 2.2). A schematic of the REA system for HONO vertical flux measurement and its field installation are shown in Fig. 1.

The sonic anemometer collects 3-dimensional wind components: two horizontal components $(u$ and $v)$ and one vertical component $(w)$, and virtual temperature of air. The controlling unit includes a computer with data acquisition hardware/software and two fast-response 3-way solenoid valves (Fluorocarbon Delta Solenoid Valve, Model DV3-144D2), one each for updraft and downdraft sampling. The wind and temperature signals from the anemometer are collected by the computer through a USB analog to digital converter (Measurement Computing, Model USB-1208FS) at a sampling frequency of $10 \mathrm{~Hz}$. Moving averages and standard deviations $\left(\sigma_{w}\right)$ of vertical wind velocity with a $5 \mathrm{~min}$ interval are updated instantaneously. The computer then determines the motion of air (updraft or downdraft) as described previously and holds the previous air motion status for about $350 \mathrm{~ms}$ (discussed in Sect. 3.2) until the air arrives at the solenoid valve system. The computer then operates the 


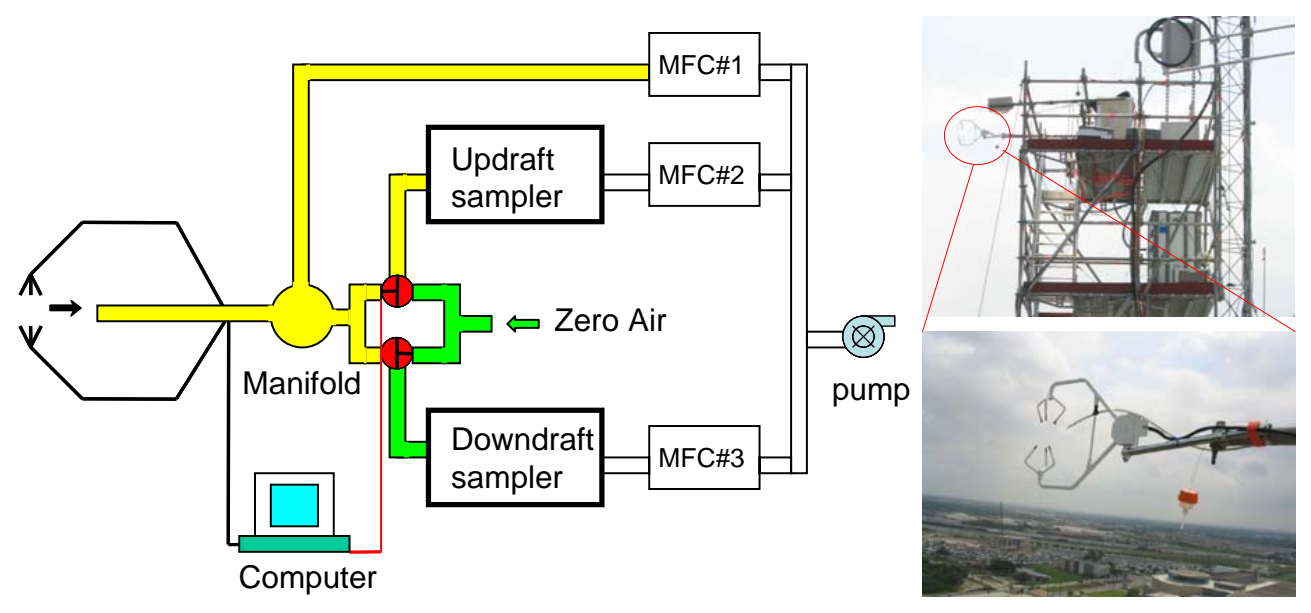

Fig. 1. Left: schematic of a Relaxed Eddy Accumulation (REA) system for HONO flux measurement. Right: pictures showing the actual instrumentation during a field study. Both the REA system and the HONO analyzer were installed on a tower.

valves accordingly to divert the air into the updraft sampler or downdraft sampler, or in case the air motion falls in the deadband (i.e., the deviation of current vertical wind velocity is greater than $-0.5 \sigma_{w}$, but less than $0.5 \sigma_{w}$ ), the valves are switched to positions to sample zero air. During field deployments, at least one of the channels (updraft or downdraft) samples zero air at any given time so all samples are diluted at the analyzers.

As shown in Fig. 1, the REA system consists of a manifold with air flow split into two flow paths: the sample flow for either the updraft or downdraft sampler and the bypass flow (mass flow control \#1 (MFC\#1) in Fig. 1). In order to keep the air flow rates through the updraft and downdraft samplers constant, HONO-free zero air from a zero air generator (Perma Pure, LLC) was fed into the samplers when an air motion fell in a "deadband" or when one sampler was sampling zero air while the other sampler was sampling ambient air in either updraft or downdraft case. The zero air flow rate was controlled by a mass flow controller at $4.51 \mathrm{~min}^{-1}$, which exceeds the total sampling flow rate of $41 \mathrm{~min}^{-1}$ during deadband periods. Extra zero air flow was vented to the ambient air through a tee connection to maintain the zero air pressure at the atmospheric pressure.

In summary, this REA system was operated according to the following steps, repeated after every sample interval of $0.1 \mathrm{~s}$ :

1. Vertical wind velocity and air temperature are read from the anemometer via a universal serial bus (USB) analog to digital converter.

2. Moving average and standard deviation in a previous $5 \mathrm{~min}$ interval are calculated and updated.

3. Based on the instantaneous vertical wind velocity and threshold of $\pm 0.5 \sigma_{w}$, valve positions are determined and the corresponding command is sent via USB port to update the valve status after waiting for the time for the air to travel through the sample line.

4. Depending on the REA valve positioning, the number of data points and average temperature statistics in the updraft/downdraft/deadband vertical wind speed interval are updated.

At the end of each averaging period (usually $30 \mathrm{~min}$ ) for flux calculation, the percentages of time for updraft, downdraft, and deadband sampling and the corresponding average temperatures are calculated and the average statistics are saved for further analyses. The computer used for the REA-HONO system has a Windows XP operation system and a data acquisition program based on Visual Basic to conduct the above calculations, control the valves, and acquire data from the anemometer and the HONO analyzer.

\subsection{HONO analyzer}

In our REA system, a HONO analyzer is used to measure HONO concentrations in updraft and downdraft air samples. Its technique is based on aqueous coil scrubbing followed by nitrite derivatization to a highly light-absorbing azo dye, which is then detected with liquid waveguide long path absorption photometry. A detailed description of this instrument can be found elsewhere (Ren et al., 2010). Here a brief description is given. Ambient air was pulled through a lightshielded Teflon tubing $(\mathrm{OD}=6.35 \mathrm{~mm}$, and $\mathrm{ID}=3.96 \mathrm{~mm}$, length $=5.3 \mathrm{~m}$ ) to a manifold at flow rate of about $11 \mathrm{~min}^{-1}$, $21 \mathrm{~min}^{-1}$ of which was fed to the HONO instrument's either updraft or downdraft sampler. The instrument was housed in an instrument rack near the anemometer. The inlet of the sampling tubing was mounted next to the anemometer sensor. Inside each sampler, ambient air was pulled through 10-turn glass coil by a vacuum pump and the air flow rate was controlled by a mass flow controller at $21 \mathrm{~min}^{-1}$. 
A phosphate buffer with a concentration of $1.0 \mathrm{mmoll}^{-1}$ $(\mathrm{pH}=6.8)$ was used as a scrubbing solution to collect HONO in the air sample. After the separation from the gas phase, the scrubbing solution was mixed with sulfanilamide (SA) and $\mathrm{N}$-(1-naphthyl) ethylenediamine (NED) reagents. The mixture was then pumped through a Teflon derivatization coil, where nitrite was converted to an azo dye, which was detected by a long path absorption photometer.

The HONO instrument was calibrated using sodium nitrite $\left(\mathrm{NaNO}_{2}\right)$ standard solutions as well as a HONO generation system (Ren et al., 2010). The detection limit of the HONO analyzer was about 3 pptv with a 2-min integration time required by the HONO sampling and analysis, and the measurement uncertainty was about $\pm 15 \%$ at a $2 \sigma$ confidence level. This uncertainty was estimated from the combined uncertainties in the nitrite standards $( \pm 5 \%)$, the sampling flow rate $( \pm 6 \%)$, the liquid flow rate through the coil to scrub HONO $( \pm 6 \%)$, the conversion efficiency of nitrite to azo dye $( \pm 10 \%)$, and the drift of absorbance of the spectrometer $( \pm 5 \%)$. Because the HONO difference in the updraft and downdraft is used to calculate HONO flux, some of the uncertainties are cancelled out (e.g., the calibration standards, the conversion efficiency of nitrite to azo dye, and the drift of absorbance of the spectrometer). So the actual accuracy of HONO flux measurement is more likely within $\pm 5-10 \%$ at a $2 \sigma$ confidence level.

\subsection{Site description}

The REA-HONO system was deployed at two field sites: one in Bakersfield, California as part of the CalNex study in summer 2010 and the other at Blodgett Forest, California during the BEARPEX II study in summer 2009. The site of the CalNex study is located at the southern end of the San Joaquin Valley in Bakersfield, California, about $6 \mathrm{~km}$ southeast of downtown Bakersfield $\left(35^{\circ} 20^{\prime} 46.2^{\prime \prime} \mathrm{N}\right.$, $118^{\circ} 57^{\prime} 55.9^{\prime \prime} \mathrm{W}, 120 \mathrm{~m}$ elevation). There are two nearby major highways: Highway 58 located at about $800 \mathrm{~m}$ north of the site and Highway 99 located at about $6 \mathrm{~km}$ west of the site. During the day, the site was influenced by the prevailing wind from downtown Bakersfield. The instrument was placed on an $18 \mathrm{~m}$ scaffolding tower, standing on an agricultural field. The height of the inlet was $13.5 \mathrm{~m}$ above the ground. HONO vertical fluxes were measured from 16 May to 29 June 2010 in this study.

The BEARPEX site is located at Blodgett Forest in the western foothills of the Sierra Nevada mountains $\left(38^{\circ} 58^{\prime} 42.4^{\prime \prime} \mathrm{N}, 120^{\circ} 38^{\prime} 3.4^{\prime \prime} \mathrm{W}, 1315 \mathrm{~m}\right.$ elevation) and has been described in detail elsewhere (e.g., Goldstein et al., 2000; Wolfe et al., 2009; Ren et al., 2010). The inlet was located on a scaffolding tower at a height of $13.5 \mathrm{~m}$ above the ground, or $\sim 5.5 \mathrm{~m}$ above the canopy of the surrounding pine trees. During this study, HONO vertical fluxes were measured from 4 July to 30 July 2009.
In both field studies, other chemical species, including ozone, detailed nitrogen species $\left(\mathrm{NO}, \mathrm{NO}_{2}, \mathrm{HONO}, \mathrm{HNO}_{3}\right.$, alkyl nitrates, and peroxy nitrates), $\mathrm{CO}$, volatile organic compounds (VOCs), and meteorological parameters, including temperature, pressure, relative humidity, wind direction, wind speed, and solar radiation, were also measured concurrently. The relatively complete suite of chemical and meteorological measurements in the both studies provides a great opportunity to examine the relationship between the measured HONO fluxes and other parameters.

\section{Characterization of the REA system}

\subsection{Proportionality coefficient, $\beta$}

The proportionality coefficient, $\beta$, is needed to calculate REA fluxes based on Eq. (1). The $\beta$-value is thought to depend on atmospheric stability (Andreas et al., 1998; Milne et al., 2001; Ammann and Meixner, 2002). Under ideal atmospheric turbulence conditions such as over flat and homogenous terrain, the proportionality, $\beta$, in Eq. (1) has a value of approximately 0.6 (Businger and Oncley, 1990; Baker et al., 1992; Katul et al., 1996) when a vertical velocity threshold of zero is used. When a non-zero threshold is used (e.g., $0.5 \sigma_{w}$ in this study) to determine updraft and downdraft air motions, the proportionality coefficient is generally constant and commonly calculated from a sensible heat flux and a vertical air temperature that correspond to the sampled up and downdrafts (Businger and Oncley, 1990; Katul et al., 1996; Bowling et al., 1998; Schade and Goldstein, 2001), as shown in the following equation:

$\beta=\frac{\overline{w^{\prime} T^{\prime}}}{\sigma_{w}\left(\bar{T}_{\text {up }}-\bar{T}_{\text {down }}\right)}$

where $w^{\prime}$ and $T^{\prime}$ are the fluctuating components of the instantaneous measured vertical wind velocity $(w)$ and air temperature $(T)$, i.e., $w^{\prime}=w-\bar{w}$ and $T^{\prime}=T-\bar{T}, \bar{T}_{\text {up }}$ and $\bar{T}_{\text {down }}$ denote the average temperatures of the same updrafts and downdrafts as the HONO samples, and $\sigma_{w}$ is the standard deviation of the vertical wind velocity over a 30-min collection period. Large uncertainties can be introduced into this calculation when the denominator in Eq. (2) is very small, i.e., during near neutral atmospheric stability, commonly observed during times when the sensible heat flux changes sign in the morning and evening hours (Park et al., 2010).

Because of the large uncertainties in the proportionality coefficient at night, a theoretical estimation of the $\beta$-value has also been established. Comparison of the $\beta$-value calculated from Eq. (2) with the theoretical estimation ensures that we can apply the daytime $\beta$-value calculated from Eq. (2) for the nighttime. According to Businger and Oncley (1990), the 
proportionality coefficient can be estimated using the following formula based on numerical simulations:

$\beta=\beta_{0} \exp \left(\frac{-0.75\left|w_{0}\right|}{\sigma_{w}}\right)$

where $\beta_{0}=\beta\left(\left|w_{0}\right|=0\right) \approx 0.6,\left|w_{0}\right|$ is the magnitude of the velocity threshold for up and down sampling (usually between 0 and $\sigma_{w}$ ) (Gaman et al., 2004). Using this equation, we calculated a $\beta$-value of 0.412 for our REA-HONO system, where $\left|w_{0}\right|=0.5 \sigma_{w}$ was used. During the field deployment, the 3-D sonic anemometer collected virtual temperature concurrently with wind data. Using concurrent observations of vertical wind velocity and temperature during the two field studies, we calculated the averaged daytime $\beta$-values to be $0.410 \pm 0.018$ for CalNex 2010 and $0.441 \pm 0.008$ for BEARPEX 2009 using Eq. (2), which are close to the value estimated from Eq. (3). The actual $\beta$ values determined from Eq. (2) in the mid-day were used in the two field studies to calculate HONO fluxes.

\subsection{Time lag and flow dynamics}

In order to minimize the time lag, i.e., the total travel time for the air through the sampling line, a manifold was used to pull a large bypass air flow $\left(\sim 91 \mathrm{~min}^{-1}\right)$ in addition to the sample flow of $21 \mathrm{~min}^{-1}$ (Fig. 1). The time lag was estimated to be about $350 \mathrm{~ms}$ based on the total air flow rate and the volume in the sample line. With a tubing inner diameter of $3.96 \mathrm{~mm}$ and a length of $5.3 \mathrm{~m}$, the calculated Reynolds number is $\sim 4100$ and is greater than the critical Reynolds number of 2300. Thus the flow in the sampling line was most likely turbulent (Bird, 1960).

\subsection{Updraft and downdraft statistics}

With the use of a dynamic velocity threshold of $\pm 0.5 \sigma_{w}$ to determine the air motion, the average fraction of time when air motion was updraft or downdraft was about $22 \%$ in the both field studies, while the air motion fell in the deadband for the remaining $56 \%$ of the time. The HONO concentrations in the updrafts and downdrafts were corrected for the sampling time fractions.

\subsection{Possible sampling artifacts due to sampling line}

In the REA-HONO system, a piece of 5.3-m long Teflon tubing was used as a sample inlet and there might be some sampling artifacts due to certain wall reactions forming HONO. The possible interferences have been tested with our HONO analyzer in the laboratory and there was no HONO loss through a longer piece of Teflon tubing (Ren et al., 2010). Furthermore, in the field we conducted an additional test with a dry annular denuder coated with sodium carbonate by connecting the denuder to the sample inlet. The denuder removes HONO efficiently but retains most of the particles, $\mathrm{NO}_{2}$, PAN, and other organic nitrates in the air flow. The

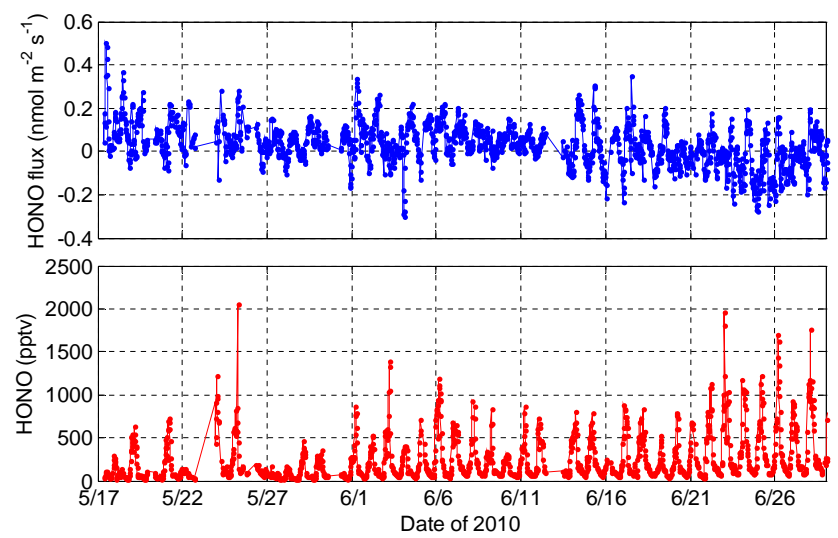

Fig. 2. Time series of HONO flux (top) and HONO concentration (bottom) measured during CalNex 2010.

signals obtained from the ambient air through the denuder were essentially the same as the signals from zero air, indicating no significant HONO interferences through the sample line. By using a large manifold flow (totally $\sim 111 \mathrm{~min}^{-1}$ ) in our configuration (Fig. 1), the possible artifacts due to sample tubing were significantly suppressed. Even if there was a small amount of artifact present, it was approximately equal in both updraft and downdraft samples, and was cancelled out as only the difference of HONO concentration between updraft and downdraft samples was used in the HONO flux calculation.

\section{Applications}

The developed REA system was deployed to measure HONO fluxes in two field studies: CalNex 2010 in Bakersfield, California and BEARPEX 2009 at Blodgett Forest, California. Measurement results of HONO fluxes, other chemical species, and meteorological parameters in the two field studies are briefly discussed below.

\subsection{CalNex 2010}

The time series of observed HONO fluxes and HONO concentrations are shown in Fig. 2. The HONO flux varied from a minimum of $-0.3 \mathrm{nmol} \mathrm{m}^{-2} \mathrm{~s}^{-1}$ (downward) to a maximum of $0.5 \mathrm{nmol} \mathrm{m}^{-2} \mathrm{~s}^{-1}$ (upward). The observed HONO exhibits a typical diurnal variation with a minimum concentration of $\sim 30 \mathrm{pptv}$ in the late afternoon and a maximum concentration of $2000 \mathrm{pptv}$ in the early morning. The observed HONO and HONO flux levels are comparable to the measurements at other urban/suburban locations (e.g., Harrison and Kitto, 1994; Stutz et al., 2002). For instance, Harrison and Kitto (1994) observed HONO fluxes varying from -0.21 to $0.53 \mathrm{nmol} \mathrm{m}^{-2} \mathrm{~s}^{-1}$ over a grassland in eastern England. Zhou et al. (2011) reported similar upward HONO fluxes with a maximum flux of $\sim 0.19 \mathrm{nmol} \mathrm{m}^{-2} \mathrm{~s}^{-1}$ during 

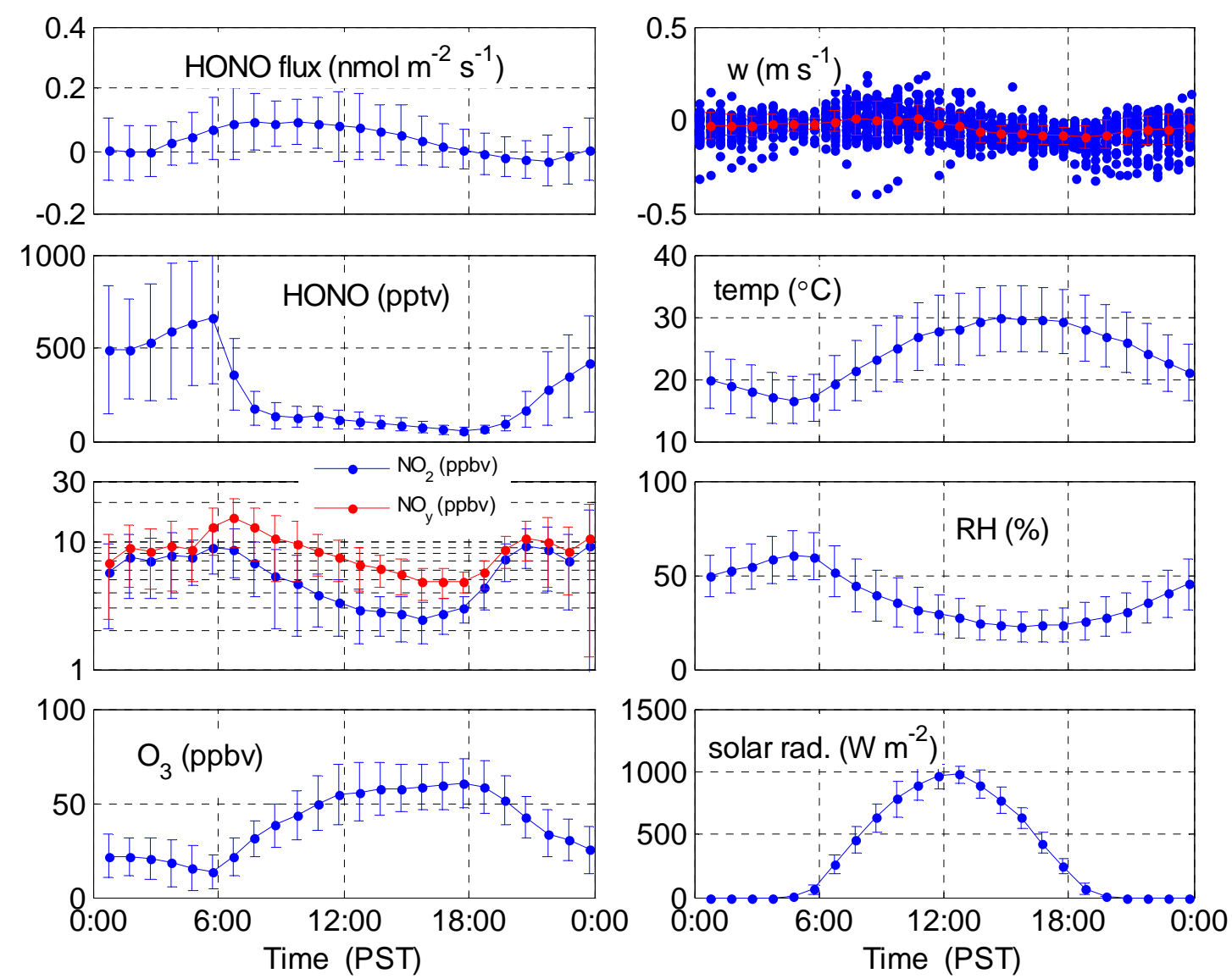

Fig. 3. Composite diurnal variations of $\mathrm{HONO}$ flux, $\mathrm{HONO}, \mathrm{NO}_{2} / \mathrm{NO}_{\mathrm{y}}, \mathrm{O}_{3}$, vertical wind velocity $(w)$, temperature, relative humidity (RH) and solar radiation measured during the CalNex 2010 field study. Hourly diurnal mean values are shown and error bars represent $1 \sigma$ deviations of the measurements in the hourly bins. For vertical wind velocity $(w)$, individual 30-min averages are also plotted as blue dots to show the variations in the data.

the day at the Program for Research on Oxidants: PHotochemistry, Emissions, and Transport (PROPHET) site located in a forested area in northern Michigan, despite lower levels of $\mathrm{NO}_{\mathrm{x}}$ observed at this site compared to typical urban/suburban sites.

The diurnal variations of chemical species and meteorological parameters are shown in Fig. 3. On average, HONO fluxes appeared to be upward during the day with a maximum of $\sim 0.1 \mathrm{nmol} \mathrm{m}^{-2} \mathrm{~s}^{-1}$ observed in the morning and were close to zero $\left(-0.007 \pm 0.017 \mathrm{nmol} \mathrm{m}^{-2} \mathrm{~s}^{-1}\right)$ at night. The observed daytime HONO fluxes are reasonable considering the moderate levels of reactive nitrogen species existing in San Joaquin Valley. Highest HONO fluxes were observed when winds were from northwest, where downtown Bakersfield is located.

Previous studies have found that there are a few photochemical homogeneous and heterogeneous processes that can produce HONO. The reaction of photolytically excited $\mathrm{NO}_{2}\left(\mathrm{NO}_{2}^{*}\right)$ with water can produce $\mathrm{HONO}$ and $\mathrm{OH}(\mathrm{Li}$ et al., 2008), although the reaction rate and yield of $\mathrm{HONO}$ and $\mathrm{OH}$ are still under debate and this mechanism likely contributes insignificantly to atmospheric HONO formation (Carr et al., 2009; Sörgel et al., 2011). Several photochemical heterogeneous processes can also form HONO. For example, the photosensitized reduction of $\mathrm{NO}_{2}$ on organic surfaces such as aromatics and humic acids can produce HONO (George et al., 2005; Stemmler et al., 2006, 2007). The photolysis of surface adsorbed nitric acid $\left(\mathrm{HNO}_{3}\right)$ and nitrate can act as a source of $\mathrm{HONO}$ and thus serve as an important pathway for the remobilization of deposited $\mathrm{HNO}_{3}$ (Zhou et al., 2002, 2003, 2011). The conversion of $\mathrm{NO}_{2}$ on fresh soot particles and secondary organic aerosols is also a source of HONO (Monge et al., 2010), although the roles of these processes are still under discussion (Stemmler et al., 2007; Sörgel et al., 2011). Lastly, the photolysis of o-nitrophenol and its methylated analogues can produce HONO (Bejan et al., 2006), but this mechanism is only important in urban areas where concentrations of nitrophenols are high. Most recently, Su et al. (2011) found that soil nitrite can release HONO and explain the strength and diurnal variation in one study. 

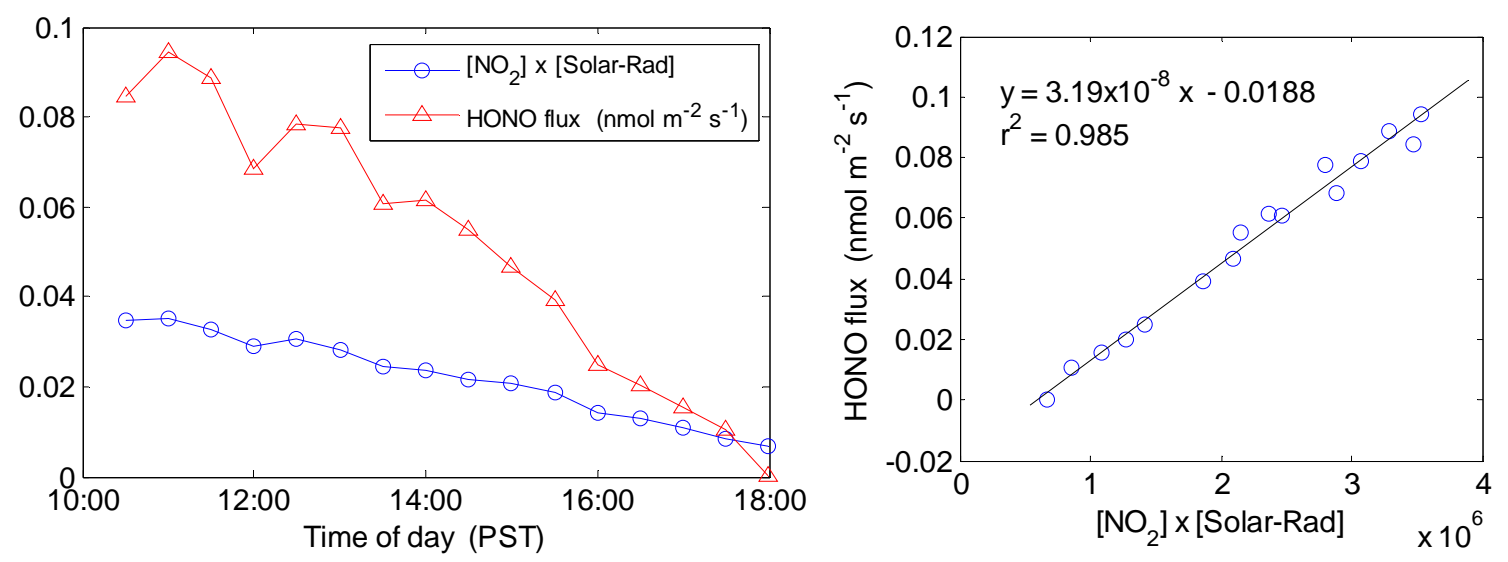

Fig. 4. Left: mean diurnal variations (in $30 \mathrm{~min}$ intervals) of HONO flux (in nmol m${ }^{-2} \mathrm{~s}^{-1}$, red triangles) and the product (multiplied by a factor of $1 \times 10^{-8}$, blue circles) of [ $\left.\mathrm{NO}_{2}\right]$ (in pptv) and solar radiation (in $\mathrm{W} \mathrm{m}^{-2}$ ). Right: scatter plot of HONO flux versus the product of $\left[\mathrm{NO}_{2}\right]$ and solar radiation. Data are shown for CalNex 2010 for hours between 10:00 and 18:00 (Pacific Standard Time, PST) when the boundary mixing layer was expected to be fully developed.

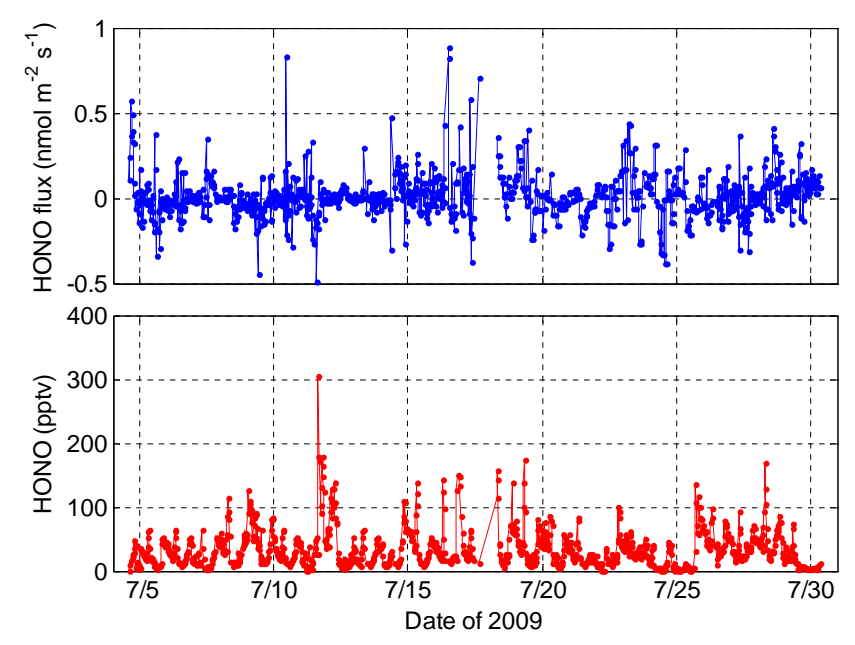

Fig. 5. Time series of HONO flux (top) and HONO concentration (bottom) observed during BEARPEX 2009.

The photochemical production of HONO near the earth's surface can contribute to HONO vertical fluxes. During CalNex 2010, we observed a very strong correlation $\left(r^{2}=\right.$ 0.985 ) between $\mathrm{HONO}$ flux and the product of $\mathrm{NO}_{2}$ concentration and solar radiation during the daytime from late morning to early evening, when the boundary mixing layer was expected to be fully developed (Fig. 4). A similar correlation between $\mathrm{NO}_{2}$ and upward $\mathrm{HONO}$ fluxes was observed by Harrison and Kitto (1994), although in this study the upward $\mathrm{HONO}$ fluxes were usually associated with higher $\mathrm{NO}_{2}$ levels ( $>10 \mathrm{ppbv}$ ) than the daytime $\mathrm{NO}_{2}$ levels $(\sim 3-5 \mathrm{ppbv})$ observed during this study. The correlation is poor between the HONO flux and $\mathrm{NO}_{2}$ only $\left(r^{2}=0.21\right)$ or between the HONO flux and solar radiation only $\left(r^{2}=0.27\right)$, suggesting that the reduction of $\mathrm{NO}_{2}$ involving sunlight might be an important HONO source in this environment, in agreement with the finding during the DOMINO (Diel Oxidant Mechanism In relation to Nitrogen Oxides) campaign in southwest Spain (Sörgel et al., 2011).

\subsection{BEARPEX 2009}

Measurements of HONO concentration and flux at Blodgett Forest during BEARPEX 2009 were quite different from those in CalNex 2010. The measured HONO levels are about one order of magnitude lower than those in CalNex 2010 (Figs. 5 and 6). This is expected because of relatively low levels of reactive nitrogen at Blodgett Forest compared to those in San Joaquin Valley. The HONO levels during BEARPEX 2009 are comparable to the levels observed at the same site during BEARPEX 2007 (Ren et al., 2010).

Compared to CalNex 2010, the daytime HONO fluxes during BEARPEX 2009 were much lower (Figs. 3 and 6). The average daytime HONO flux was close to zero $\left(-0.004 \pm 0.024 \mathrm{nmol} \mathrm{m}^{-2} \mathrm{~s}^{-1}\right)$ at this forested site. Because of the lower HONO fluxes during BEARPEX 2009 compared to those of CalNex 2010, the correlation between HONO flux and the product of $\mathrm{NO}_{2}$ and solar radiation during BEARPEX 2009 is much weaker $\left(r^{2}=0.43\right)$, compared to the strong correlation observed during CalNex 2010. If we apply the relationship between HONO flux and the product of $\mathrm{NO}_{2}$ and solar radiation during CalNex 2010 in Fig. 4 (a slope of $\sim 3 \times 10^{-8} \mathrm{nmol} \mathrm{m}^{-2} \mathrm{~s}^{-1}$ per pptv of $\mathrm{NO}_{2}$ and per $\mathrm{W} \mathrm{m}^{-2}$ of solar radiation) to BEARPEX 2009, the corresponding HONO flux is about $0.007 \mathrm{nmol} \mathrm{m}^{-2} \mathrm{~s}^{-1}$ in the midday when the $\mathrm{NO}_{2}$ concentration was about 300 pptv and the solar radiation was about $800 \mathrm{~W} \mathrm{~m}^{-2}$ during BEARPEX 2009. This value is about the average level we observed at Blodgett during the day and is below the detection limit of the REA-HONO system $\left(\sim 0.01 \mathrm{nmol} \mathrm{m}^{-2} \mathrm{~s}^{-1}\right)$. 

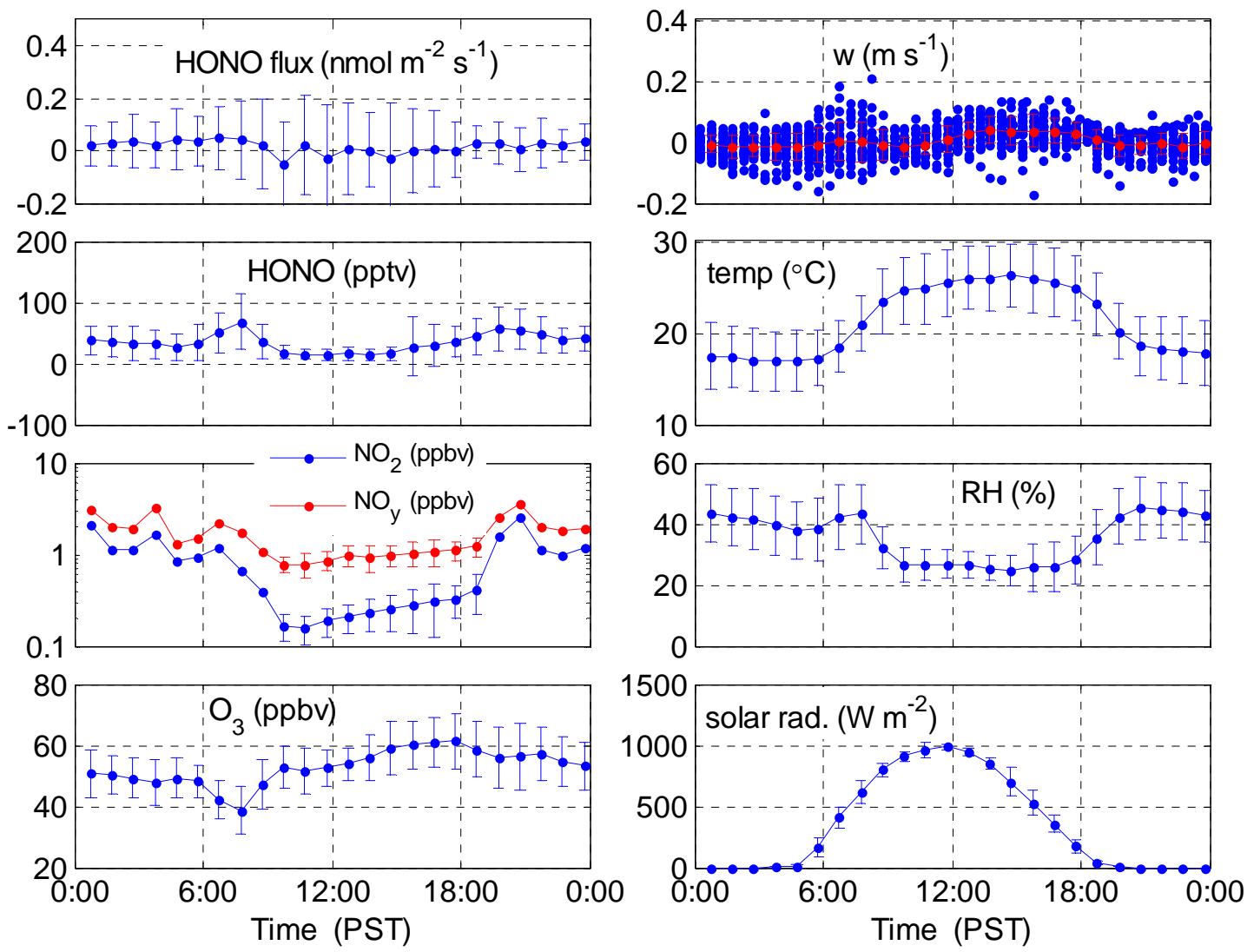

Fig. 6. Diurnal variations of $\mathrm{HONO}$ flux, $\mathrm{HONO}, \mathrm{NO}_{2} / \mathrm{NO}_{\mathrm{y}}, \mathrm{O}_{3}$, vertical wind velocity $(w)$, temperature, relative humidity $(\mathrm{RH})$ and solar radiation measured during the BEARPEX 2009 field study. Hourly diurnal mean values are shown and error bars represent $1 \sigma$ deviations of the measurements in the hourly bins. For vertical wind velocity $(w)$, individual 30-min averages are also plotted as blue dots to show the variations in the data.

Much smaller HONO fluxes were observed during BEARPEX 2009 than at the PROPHET site in a broadleaf forest in Northern Michigan, where significant daytime upward HONO fluxes were observed with a maximum of HONO flux of $0.19 \mathrm{nmol} \mathrm{m}^{-2} \mathrm{~s}^{-1}$ observed around noontime (Zhou et al., 2011). This difference is consistent with the lower observed HONO concentrations ( $20-30$ pptv) during the midday at Blodgett Forest compared to HONO levels (60-120 pptv) at the PROPHET site (Zhou et al., 2011) and some other forested areas (Acker et al., 2006; Ren et al., 2006). We attribute this difference to the overall low acid precipitation and thus high $\mathrm{pH}$ of the soil in the western US including California. Because of the high soil $\mathrm{pH}$, the equilibrium of HONO/nitrite in the soil would be shifted to nitrite, leading to a high HONO deposition to the soil or low HONO production from the earth surfaces and thus low atmospheric HONO levels (Ren et al., 2010; Zhou et al., 2011). This is also in line with the recent study by Su et al. (2011) in which they found that low $\mathrm{pH}$ favored HONO formation from soil nitrite.

\section{Summary}

In this work a REA-HONO system was developed to measure atmospheric HONO vertical fluxes. With a dynamic velocity threshold of $\pm 0.5 \sigma_{w}$ to determine air motion and using measured temperature as a tracer, the flux proportionality coefficient, $\beta$, was determined to be $0.42 \pm 0.02$ in two field deployments, in good agreement with the theoretical estimation of 0.412 .

The developed relaxed eddy accumulation (REA) system was successfully deployed in two field studies to measure vertical HONO fluxes. The measurements show significant daytime upward HONO fluxes in San Joaquin Valley during CalNex 2010, with a maximum HONO flux of $\sim 0.1 \mathrm{nmol} \mathrm{m}^{-2} \mathrm{~s}^{-1}$ observed in the morning. The upward fluxes correspond to significant HONO production near the surface. HONO fluxes appeared to be close to zero at night. During CalNex 2010, a strong linear correlation between HONO flux and the product of $\mathrm{NO}_{2}$ and solar radiation was observed for the daytime hours when the boundary mixing layer was fully developed, indicating that the photochemical production of $\mathrm{HONO}$ involving $\mathrm{NO}_{2}$ and sunlight may be 
dominant in HONO production and thus the upward fluxes in this environment.

On the other hand, the HONO fluxes observed at Blodgett Forest during BEARPEX 2009 were low in magnitude and close to zero on average, partly because of the overall low reactive nitrogen levels in the environment. The low HONO fluxes observed at Blodgett Forest are quite different from the observations at the PROPHET site in northern Michigan (Zhou et al., 2011). This is consistent with the lower daytime HONO levels observed at Blodget Forest compared to the HONO observations at the PROPHET site and in other forested areas probably due to higher soil $\mathrm{pH}$ and thus lower HONO production from the ground surfaces in the Blodgett Forest region.

In order to better understand the vertical HONO flux and its role in atmospheric HONO chemistry, more measurements of HONO flux are needed, especially in a variety of environments, including polluted urban environments. The REA-HONO system will be further deployed in future field studies.

Acknowledgements. We thank Sierra Pacific Industries for the use of their land and the University of California, Berkeley, Center for Forestry, Blodgett Forest Research Station for cooperation in facilitating the BEARPEX research. We also thank the Kern County and University of California Cooperative Extension office in Bakersfield for use of their land and thank the staff (particularly John Karlik and Rick Ramirez) for cooperation in facilitating this research. This work was partially supported by NSF (AGS-0914619), Houston Advanced Research Center (HARC), and University of Miami Provost Research Award. Much of the site infrastructure and core measurements were funded by the National Science Foundation Atmospheric Chemistry Program for BEARPEX 2009 (Grant 0922562), and the California Air Resources Board for CalNex 2010 (Contract 08-316). We acknowledge the helpful suggestions by two anonymous reviewers.

Edited by: J. Stutz

\section{References}

Acker, K., Möller, D., Wieprecht, W., Meixner, F. X., Bohn, B., Gilge, S., Plass-Dülmer, C., and Berresheim, H.: Strong production of $\mathrm{OH}$ from $\mathrm{HNO}_{2}$ at a rural mountain site, Geophys. Res. Lett., 33, L02809, doi:10.1029/2005GL024643, 2006.

Alicke, B., Geyer, A., Hofzumahaus, A., Holland, F., Konrad, S., Pätz, H.-W., Schäfer, J., Stutz, J., Volz-Thomas, A., and Platt, U.: $\mathrm{OH}$ formation by HONO photolysis during the BERLIOZ experiment, J. Geophys. Res., 108, 8247, doi:10.1029/2001JD000579, 2003.

Ammann, C. and Meixner, F. X.: Stability dependence of the relaxed eddy accumulation coefficient for various scalar quantities, J. Geophys. Res., 107, 8083, doi:10.1029/2001JD000523, 2002.

Andreas, E. L., Hill, R. J., Gosz, J. R., Moore, D. I., Otto, W. D., and Sarma, A. D.: Statistics of surface-layer turbulence over terrain with metre-scale heterogeneity, Bound.-Lay. Meteorol., 86, 379408, 1998.
Baker, J. M., Norman, J. M., and Bland, W. L.: Field-scale application of flux measurement by conditional sampling, Agr. Forest Meteorol., 62, 31-52, 1992.

Bash, J. O. and Miller, D. R.: A relaxed eddy accumulation system for measuring surface fluxes of total gaseous mercury, J. Atmos. Ocean Tech., 25, 244-257, 2008.

Beine, H. J., Amoroso, A., Esposito, G., Sparapani, R., Ianniello, A., Georgiadis, T., Nardino, M., Bonasoni, P., Cristofanelli, P., and Dominé, F.: Deposition of atmospheric nitrous acid on alkaline snow surfaces, Geophys. Res. Lett., 32, L10808, doi:10.1029/2005GL022589, 2005.

Beine, H. J., Amoroso, A., Dominé, F., King, M. D., Nardino, M., Ianniello, A., and France, J. L.: Surprisingly small HONO emissions from snow surfaces at Browning Pass, Antarctica, Atmos. Chem. Phys., 6, 2569-2580, doi:10.5194/acp-6-2569-2006, 2006.

Bejan, I., Abd El Aal, Y., Barnes, I., Benter, T., Bohn, B., Wiesen, P., and Kleffmann, J.: The photolysis of ortho-nitrophenols: a new gas phase source of HONO, Phys. Chem. Chem. Phys., 8, 2028-2035, 2006.

Bertman, S., Marchewka, M., and King, J.: A method for the measurement of nitrous acid flux using relaxed eddy accumulation, Eos Trans. AGU, 84(46), Fall Meet. Suppl., Abstract A32A0131, San Francisco, CA, 2003.

Bird, R. B., Stewart, W. E., and Lightfoot, E. N.: Transport phenomena, John Wiley \& Sons, New York, 1960.

Bowling, D. R., Turnipseed, A. A., Delany, A. C., Baldocchi, D. D., Greenberg, J. P., and Monson, R. K.: The use of relaxed eddy accumulation to measure biosphere-atmosphere exchange of isoprene and other biological trace gases, Oecologia, 116, 306-315, 1998.

Bowling, D. R., Delany, A. C., Turnipseed, A. A., Baldocchi, D. D., and Monson, R. K.: Modification of the relaxed eddy accumulation technique to maximize measured scalar mixing ratio differences in updrafts and downdrafts, J. Geophys. Res., 104, 9121-9133, 1999.

Businger, J. A. and Oncley, S. P.: Flux measurement with conditional sampling, J. Atmos. Ocean. Tech., 7, 349-35, 1990.

Carr, S., Heard, D. E., and Blitz, M. A.: Comment on "Atmospheric hydroxyl radical production from electronically excited $\mathrm{NO}_{2}$ and $\mathrm{H}_{2} \mathrm{O}$ ", Science, 324, 336b, doi:10.1126/science.1166669, 2009.

Cobos, D. R., Baker, J. M., and Nater, E. A.: Conditional sampling for measuring mercury vapor fluxes, Atmos. Environ., 36, 43094321, 2002.

Dabberdt, W. F., Lenschow, D. H., Horst, T. W., Zimmerman, P. R., Oncley, S. P., and Delany, A. C.: Atmosphere-surface exchange measurements, Science, 260, 1472-1481, 1993.

Desjardins, R. L.: A study of carbon-dioxide and sensible heat fluxes using the eddy correlation technique, Ph.D. dissertation, Cornell University, 189 pp., 1972.

Gallagher, M. W., Clayborough, R., Beswick, K. M., Hewitt, C. N., Owen, S., Moncrieff, J., and Pilegaard, K.: Assessment of a relaxed eddy accumulation for measurements of fluxes of biogenic volatile organic compounds: study over arable crops and a mature beech forest, Atmos. Environ., 34, 2887-2899, 2000.

Gaman, A., Rannik, Ü., Aalto, P., Pohja, T., Siivola, E., Kulmala, M., and Vesala, T.: Relaxed eddy accumulation system for sizedresolved aerosol particle flux measurements, J. Atmos. Ocean. Tech., 21, 933-943, 2004. 
George, C., Strekowski, R. S., Kleffmann, J., Stemmler, K., and Ammann, M.: Photoenhanced uptake of gaseous $\mathrm{NO}_{2}$ on solid organic compounds: A photochemical source of HONO?, Faraday Discussion, 130, 195-210, 2005.

Goldstein, A. H., Hultman, N. E., Fracheboud, J. M., Bauer, M. R., Panek, J. A., Xu, M., Qi, Y., Guenther, A. B., and Baugh, W.: Effects of climate variability on the carbon dioxide, water, and sensible heat fluxes above a ponderosa pine plantation in the Sierra Nevada (CA), Agr. Forest Meteorol., 101, 113-129, 2000.

Guenther, A., Baugh, W., Davis, K., Hampton, G., Harley, P., Klinger, L., Vierling, L., Zimmerman, P., Allwine, E., Dilts, S., Lamb, B., Westberg, H., Baldocchi, D., Geron, C., and Pierce, T.: Isoprene fluxes measured by enclosure, relaxed eddy accumulation, surface layer gradient, mixed layer gradient, and mixed layer mass balance techniques, J. Geophys. Res., 101, 1855518567, 1996.

Harrison, R. M. and Kitto, A.-M. N.: Evidence for a surface source of atmospheric nitrous acid, Atmos. Environ., 28, 1089-1094, 1994.

Honrath, R. E., Lu, Y., Peterson, M. C., Dibb, J. E., Arsenault, M. A., Cullen, N. J., and Steffen, K.: Vertical fluxes of $\mathrm{NO}_{\mathrm{x}}$, HONO, and $\mathrm{HNO}_{3}$ above the snowpack at Summit, Greenland, Atmos. Environ., 36, 2629-2640, 2002.

Hornsby, K. E., Flynn, M. J., Dorsey, J. R., Gallagher, M. W., Chance, R., Jones, C. E., and Carpenter, L. J.: A Relaxed Eddy Accumulation (REA)-GC/MS system for the determination of halocarbon fluxes, Atmos. Meas. Tech., 2, 437-448, doi:10.5194/amt-2-437-2009, 2009.

Katul, G. G., Finkelstein, P. L., Clarke, J. F., and Ellestad, T. G.: An investigation of the conditional sampling method used to estimate fluxes of active, reactive, and passive scalars, J. Appl. Meteorol., 35, 1835-1845, 1996.

Kleffmann, J., Gavriloaiei, T., Hofzumahaus, A., Holland F., Koppmann, R., Rupp, L., Schlosser, E., Siese, M., and Wahner, A.: Daytime formation of nitrous acid: a major source of $\mathrm{OH}$ radicals in a forest, Geophys. Res. Lett., 32, L05818, doi:10.1029/2005GL022524, 2005.

Li, S., Mathews, J., and Sinha, A.: Atmospheric hydroxyl radical production from electronically excited $\mathrm{NO}_{2}$ and $\mathrm{H}_{2} \mathrm{O}$, Science, 319, 1657-1660, 2008.

Mao, J., Ren, X., Chen, S., Brune, W. H., Chen, Z., Martinez, M., Harder, H., Lefer, B., Rappenglück, B., Flynn, J., and Leuchner, M.: Atmospheric oxidation capacity in the summer of Houston 2006: Comparison with summer measurements in other metropolitan studies, Atmos. Environ., 44, 4107-4115, 2010.

Meyers, T. P., Luke, W. T., and Meisinger, J. J.: Fluxes of ammonia and sulfate over maize using relaxed eddy accumulation, Agr. Forest Meteorol., 136, 203-213, 2006.

Milne, R., Mennim, A., and Hargreaves, K.: The value of the beta coefficient in the relaxed eddy accumulation method in terms of fourth-order moments, Bound.-Lay. Meteorol., 101, 359-373, 2001

Monge, M. E., D’Anna, B., Mazri, L., Giroir-Fendler, A., Ammann, M., Donaldson, D. J., and George, C.: Light changes the atmospheric reactivity of soot, Proc. Natl. Acad. Sci., 107, 66056609, 2010.

Neftel, A., Blatter, A., Hesterberg, R., and Staffelbach, Th.: Measurements of concentration gradients of $\mathrm{HNO}_{2}$ and $\mathrm{HNO}_{3}$ over a semi-natural ecosystem, Atmos. Environ., 30, 3017-3025, 1996.
Nie, D., Kleindienst, T. E., Arnts, R. R., and Sickles, J. E. II: The design and testing of a relaxed eddy accumulation system, J. Geophys. Res., 100, 11415-11423, 1995.

Olofsson, M., Ek-Olausson, B., Ljungstrom, E., and Langer, S.: Flux of organic compounds from grass measured by relaxed eddy accumulation technique, J. Environ. Monit., 5, 963-970, 2003.

Olofsson, M., Sommar, J., Ljugstöm, E., Andersson, M., and Wängberg, I.: Application of relaxed eddy accumulation technique to quantify $\mathrm{Hg}^{0}$ fluxes over modified soil surfaces, Water Air Soil Pollut., 167, 331-352, 2005.

Park, C, Schade, G. W., and Boedeker, I.: Flux measurements of volatile organic compounds by the relaxed eddy accumulation method combined with a GC-FID system in urban Houston, Texas, Atmos. Environ., 44, 2605-2614, 2010.

Pattey, E., Desjardins, R. L., and Rochette, P.: Accuracy of the relaxed eddy-accumulation technique, evaluated using $\mathrm{CO}_{2}$ flux measurements, Bound. Layer Meteorol., 66, 341-355, 1993.

Pattey, E., Desjardins, R. L., Westberg, H., Lamb, B., and Zhu, T.: Measurements of isoprene emissions over a black spruce stand using a tower-based relaxed eddy-accumulation system, J. Appl. Meteorol., 38, 870-877, 1999.

Ren, X., Brune, W. H., Oliger, A., Metcalf, A. R., Simpas, J. B., Shirley, T., Schwab, J. J., Bai, C., Roychowdhury, U., Li, Y., Cai, C., Demerjian, K. L., He, Y., Zhou, X., Gao, H., and Hou, J.: $\mathrm{OH}, \mathrm{HO}_{2}$ and $\mathrm{OH}$ reactivity during the PMTACS-NY Whiteface Mountain 2002 campaign: Observations and model comparison, J. Geophys. Res., 111, D10S03, doi:10.1029/2005JD006126, 2006.

Ren, X., Gao, H., Zhou, X., Crounse, J. D., Wennberg, P. O., Browne, E. C., LaFranchi, B. W., Cohen, R. C., McKay, M., Goldstein, A. H., and Mao, J.: Measurement of atmospheric nitrous acid at Bodgett Forest during BEARPEX2007, Atmos. Chem. Phys., 10, 6283-6294, doi:10.5194/acp-10-6283-2010, 2010.

Schade, G. W. and Goldstein, A. H.: Fluxes of oxygenated volatile organic compounds from a ponderosa pine plantation, J. Geophys. Res., 106, 3111-3123, 2001.

Schery, S. D., Wasiolek, P. T., Nemetz, B. M., and Yarger, F. D.: Relaxed eddy accumulation for flux measurement of nanometersize particles, Aerosol Sci. Technol., 28, 159-172, 1998.

Sörgel, M., Regelin, E., Bozem, H., Diesch, J.-M., Drewnick, F., Fischer, H., Harder, H., Held, A., Hosaynali-Beygi, Z., Martinez, M., and Zetzsch, C.: Quantification of the unknown HONO daytime source and its relation to $\mathrm{NO}_{2}$, Atmos. Chem. Phys. Discuss., 11, 15119-15155, doi:10.5194/acpd-11-15119-2011, 2011.

Stemmler, K., Ammann, M., Dondors, C., Kleffmann, J., and George, C.: Photosensitized reduction of nitrogen dioxide on humic acid as a source of nitrous acid, Nature, 440, 195-198, 2006.

Stemmler, K., Ndour, M., Elshorbany, Y., Kleffmann, J., D’Anna, B., George, C., Bohn, B., and Ammann, M.: Light induced conversion of nitrogen dioxide into nitrous acid on submicron humic acid aerosol, Atmos. Chem. Phys., 7, 4237-4248, doi:10.5194/acp-7-4237-2007, 2007.

Stutz, J., Alicke, B., and Neftel, A.: Nitrous acid formation in the urban atmosphere: Gradient measurements of $\mathrm{NO}_{2}$ and HONO over grass in Milan, Italy, J. Geophys. Res., 107, 8192, doi:10.1029/2001JD000390, 2002.

Su, H., Cheng, Y., Oswald, R., Behrendt, T., Trebs, I., Meixner, 
F. X., Andreas, M. O., Cheng, P., Zhang, Y., and Pöschl, U.: Soil nitrite as a source of atmospheric $\mathrm{HONO}$ and $\mathrm{OH}$ radicals, Science, 333, 1616-1618, doi:10.1126/science.1207687, 2011.

Valentini, R., Greco, S., Seufert, G., Bertin, N., Ciccioli, P., Cecinato, A., Brancaleoni, E., and Erattoni, M.: Fluxes of biogenic VOC from Mediterranean vegetation by trap enrichment relaxed eddy accumulation, Atmos. Environ., 31, 229-238, 1997.

Wolfe, G. M., Thornton, J. A., Yatavelli, R. L. N., McKay, M., Goldstein, A. H., LaFranchi, B., Min, K.-E., and Cohen, R. C.: Eddy covariance fluxes of acyl peroxy nitrates (PAN, PPN and MPAN) above a Ponderosa pine forest, Atmos. Chem. Phys., 9, 615-634, doi:10.5194/acp-9-615-2009, 2009.

Xi, N., Zhong, P., Beverland, I. J., Oneill, D. H., Scott, S. L., and Moncrieff, J. B.: Design, construction and operation of flux measurement systems using the conditional sampling technique, Atmos. Environ., 30, 3209-3220, 1996.
Zhou, X., He, Y., Huang, G., Thornberry, T. D., Carroll, M. A., and Bertman, S. B.: Photochemical production of nitrous acid on glass sample manifold surface, Geophys. Res. Lett., 29, 1681, doi:10.1029/2002GL015080, 2002.

Zhou, X., Gao, H., He, Y., Huang, G., Bertman, S., Civerolo, K., and Schwab, J.: Nitric acid photolysis on surfaces in low- $\mathrm{NO}_{x}$ environments: significant atmospheric implications, Geophys. Res. Lett., 30, 2217, doi:10.1029/2003GL018620, 2003.

Zhou, X., Zhang, N., TerAvest, M., Tang, D., Hou, J., Bertman, S., Alaghmand, M., Shepson, P. B., Carroll, M. A., Griffith, S., Dusanter, S., and Stevens, P. S.: Nitric acid photolysis on forest canopy surface as a source for troposphere nitrous acid, Nat. Geosci., 4, 440-443, doi:10.1038/ngeo1164, 2011.

Zhu, T., Pattey, E., and Desjardins, R. L.: Relaxed eddy accumulation technique for measuring ammonia volatilization, Environ. Sci. Technol., 34, 199-203, 2000. 